\title{
Article \\ Cold Stress during Flowering Alters Plant Structure, Yield and Seed Quality of Different Soybean Genotypes
}

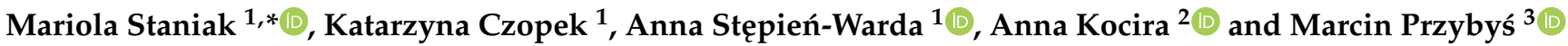 \\ 1 Department of Forage Crop Production, Institute of Soil Science and Plant Cultivation- \\ State Research Institute, 24-100 Puławy, Poland; kczopek@iung.pulawy.pl (K.C.); \\ astepien@iung.pulawy.pl (A.S.-W.) \\ 2 Institute of Agricultural Sciences, State School of Higher Education in Chełm, Pocztowa 54, \\ 22-100 Chełm, Poland; akocira@pwsz.chelm.pl \\ 3 Department of Plant Breeding and Biotechnology, Institute of Soil Science and Plant Cultivation- \\ State Research Institute, 24-100 Puławy, Poland; mprzybys@iung.pulawy.pl \\ * Correspondence: staniakm@iung.pulawy.pl
}

Citation: Staniak, M.; Czopek, K.; Stẹpień-Warda, A.; Kocira, A.; Przybyś, M. Cold Stress during Flowering Alters Plant Structure, Yield and Seed Quality of Different Soybean Genotypes. Agronomy 2021, 11, 2059. https://doi.org/10.3390/ agronomy11102059

Academic Editor: Alfonso Albacete

Received: 14 September 2021

Accepted: 12 October 2021

Published: 13 October 202

Publisher's Note: MDPI stays neutral with regard to jurisdictional claims in published maps and institutional affiliations.

Copyright: (c) 2021 by the authors. Licensee MDPI, Basel, Switzerland. This article is an open access article distributed under the terms and conditions of the Creative Commons Attribution (CC BY) license (https:// creativecommons.org/licenses/by/ $4.0 /)$.

\begin{abstract}
The objective of the study was to evaluate the effect of cold stress at flowering stage on plant structure, yield and chemical composition of seeds of 15 soybean cultivars. The study was conducted in 2019-2020, using the complete randomization method, in three replications. Fifteen soybean cultivars belonging to three maturity groups: early (EC), middle-early (MC) and late (LC) cultivars were included. Weekly cold stress $\left(17 / 13^{\circ} \mathrm{C}\right.$ day/night) was applied at plant flowering stage. In the control treatment, plants were kept under natural conditions $\left(24 / 17^{\circ} \mathrm{C}\right.$ day $/$ night $)$. Our research showed that cold stress negatively influenced the elements of plant structure: height, number of nodes, stem dry mass, number and weight of pods, number and weight of seeds per plant, as well as yield of soybean seeds, reducing it on average by $24 \%$, as compared to the control treatment. The highest yield decrease was found in LC cultivars (31.2\%), while a smaller and similar one in EC and MC cultivars (by 19.7 and 20.1\%, respectively). Significant varietal differences were found for plant biometric traits and seed yield. EC cultivars had the lowest set first pod, as well as the lowest number of nodes, number of pods and seeds, pod and seed weight per plant, and seed yield. MC cultivars had the highest set first pod, and the smallest stem DM and seed yield average by $29.2 \%$ higher compared to EC cultivars. LC cultivars had the highest stem DM, number of pods and seeds, and pod and seed weight per plant compared to the other cultivar groups, and yield by $22.8 \%$ higher compared to EC cultivars. The experimental factors significantly affected crude protein, crude fat, and crude ash content, while they did not differentiate water-soluble carbohydrate and crude fiber content. Cold stress at the flowering stage caused a significant increase in protein content (by $4.1 \%$ on average) and ash content (by $3.8 \%$ ) and a decrease in fat concentration (by $6.9 \%$ ) in soybean seeds. Differences in nutrient content among cultivars were a genetic trait not related to cultivar maturity.
\end{abstract}

Keywords: soybean; cold stress; cultivar; yield; plant structure; chemical composition of seeds

\section{Introduction}

Population growth and strong demand for oil and feed protein contributed to a global increase in soybean acreage in the late 20th and early 21st centuries. Compared to 1970, soybean acreage in 2019 increased from 29.5 to 120.5 million hectares and production increased more than four times from 81 to nearly 334 million tons. There has also been an increase in soybean yields from 1.48 to $2.77 \mathrm{t} \cdot \mathrm{ha}^{-1}$ [1]. Soybean seeds contain around 330 to $450 \mathrm{~g} \mathrm{~kg}^{-1}$ of protein with a favorable amino acid composition and a biological value similar to beef protein, about 180 to $240 \mathrm{~g} \mathrm{~kg}^{-1}$ of crude fat, of which more than half are unsaturated fatty acids, and around 55 to $80 \mathrm{~g} \mathrm{~kg}^{-1}$ of crude fiber [2]. Moreover, they are a source of lecithin, vitamins, mineral salts and biologically active compounds—isoflavones [3]. In addition 
to the consumption and fodder purposes of soybean, the cultivation of soybean as a legume is additionally economically and ecologically beneficial, resulting from the nitrogen fixation by nodule bacteria Bradyrhizobium japonicum living in symbiosis with the roots of these plants. Under favorable conditions, soybean can bind from 50 to $100 \mathrm{~kg} \mathrm{~N}^{-1}$, which allows to cover the nitrogen demand by $30-60 \%$ [4]. Thus, mineral nitrogen fertilization can be significantly reduced, which is of great importance for the protection of the natural environment and brings material benefits.

Climatic conditions are not favorable for soybean cultivation in Poland. The limiting factors are high thermal requirements of this species and sensitivity to day length [5-7]. According to Câmara et al. [8], photoperiod and temperature are the most important factors affecting the growth and development of soybean, while at the same time severely limiting the range of its cultivation, with numerous studies indicating that early-maturing cultivars grown in higher latitudes (cooler climate) are less sensitive to day length than late-maturing grown in warmer climates $[9,10]$. Soybean is temperature-sensitive from emergence to maturity, but the critical period associated with particular sensitivity to low temperatures is the flowering stage, where a biological minimum is considered to be a temperature range of $17-18{ }^{\circ} \mathrm{C}$, while the optimum is $22-25^{\circ} \mathrm{C}$ [5]. A drop in average air temperature below $15{ }^{\circ} \mathrm{C}$ causes growth retardation and inhibition of new leaf and shoot production, while a drop below $10^{\circ} \mathrm{C}$ may even cause plants to fail to enter the flowering stage [8]. Ohnishi et al. [11] showed that low temperatures $\left(15 / 10{ }^{\circ} \mathrm{C}\right.$ day/night $) 3-4$ days before flowering, had a negative effect on the fertilization process, and consequently on pod setting and seed yield. In a study by Nawracała [12], the number of flowers on the plant and on the main shoot depended on the temperature during the inflorescence formation period. Soybean, on the other hand, responds favorably to higher temperatures throughout the growing season, but only up to $32-38^{\circ} \mathrm{C}$. Very high temperatures during the flowering also result in a reduction in the number and weight of seeds per plant and consequently reduce yield [13-15]. According to Mourtzinis et al. [16], adverse weather events from 1994 to 2013 in the United States, associated with high variability in precipitation during the growing season and high temperatures resulted in a 30\% reduction in soybean seed production and USD 11 billion in economic losses.

The basis of breeding new cultivars is the consolidation of favorable traits affecting the technological and utilitarian value of plants, such as yield potential, chemical composition, or resistance to stress factors. With new breeding techniques, it is possible to accelerate varietal progress to produce genotypes adapted to specific environmental conditions [17]. The most important adaptive traits in soybean include length of the growing season and flowering time [18]. Under southwestern Polish conditions, as the growing season lengthened, soybean yields increased by, an average of $30 \mathrm{~kg} \mathrm{ha}^{-1}$ per day [2]. However, cultivation of late and very late cultivars in the northern part of Poland is risky due to a shorter growing season (by about 30-35 days) [19] and problems with plant maturity. The warming of climate favors the cultivation of thermophilic species in higher latitudes, but breeding work on soybean in Europe and in Poland should lead, first of all, to the production of cultivars with a shorter growing period, increased productivity, and a higher embedded first pod [20-22].

Soybean has a wide range of variation in morphological and physiological traits that are modified by habitat conditions. Sensitivity to flowering transition is a characteristic of this species, but there is also considerable variation in temperature response among soybean genotypes [23,24]. Gass et al. [5] showed variation among 10 soybean genotypes in cold tolerance of $3{ }^{\circ} \mathrm{C}$. Other authors have also demonstrated genotypic differences in pod setting ability after low temperature exposure correlated with cold tolerance $[25,26]$. Cold stress disrupts bioenergetic processes, causes changes in metabolism, and contributes to damage to cellular structures, leading to stunted plant growth and development, resulting in reduced yield and poorer quality [27]. Changes in plant metabolism depend on the temperature range, duration of stress, and rate of temperature decline [28]. 
The chemical composition of soybean seeds depends on the genetic characteristics of the cultivar and environmental factors such as length of the growing season, soil type, weather conditions, and biotic and abiotic stresses. Protein and fat contents are largely shaped by the pattern of moisture and thermal conditions during vegetation [29-31], with a negative correlation shown between protein content and fat content and seed yield [32,33]. Mourtzinis et al. [34] showed an increase in crude fat content in soybean seeds under higher temperature conditions, while Kumar et al. [35] proved a positive relationship between temperature and protein content and a negative relationship between temperature and fat concentration.

The aim of this study was to evaluate the effect of 7-day cold stress at flowering stage on plant structure as well as yield and chemical composition of seeds of 15 soybean cultivars belonging to three maturity groups.

\section{Materials and Methods}

\subsection{Plant Material}

The pot experiment was conducted in 2019-2020 in the greenhouse of Institute of Soil Science and Plant Cultivation-State Research Institute in Puławy, Poland [51 $24^{\prime} 59^{\prime \prime} \mathrm{N}$, $\left.21^{\circ} 58^{\prime} 09^{\prime \prime} \mathrm{E}\right]$ under partially controlled conditions. The research treatments were 15 cultivars of soybean Glycine max (L.) Merr., listed in the EU Common Catalogue of Varieties of Agricultural Plant Species [36]. The tested cultivars belonged to three maturity groups [37]: very early and early cultivars (EC): Aldana, Annushka, Augusta, Erica, Oressa (length of growing season 124-129 days), medium-early cultivars (MC): Abelina, Maja, Mavka, Merlin, Sculptor (136-139 days) and late and very late cultivars (LC): Aligator, GL Melanie, Lissabon, Madlen, Petrina (140-147 days).

\subsection{Experimental Conditions}

The soil from the arable layer of the field, was mixed with sand in a ratio of 5:2. The soil was characterized by the following content of available mineral components (g.100 g $\mathrm{g}^{-1}$ of soil): $\mathrm{P}_{2} \mathrm{O}_{5} 32.7, \mathrm{~K}_{2} \mathrm{O} 12.2, \mathrm{Mg} 11.0, \mathrm{~S} 1.34$ and microelements $\left(\mathrm{mg} \cdot \mathrm{kg}^{-1}\right.$ of soil): $\mathrm{Cu} 7.6, \mathrm{Zn} 24.1, \mathrm{Mn} 213, \mathrm{~B} 7.2, \mathrm{Mb}<0.2$. Organic C content was $0.87 \%$, soil reaction $\mathrm{pH}_{\mathrm{KCl}}$ 6.9. Pre-sowing fertilization was performed with macronutrients $\left(\mathrm{g} \mathrm{pot}^{-1}\right)$ : nitrogen $0.5\left(\mathrm{NH}_{4} \mathrm{NO}_{3}\right)$, phosphorus $1.0\left(\mathrm{KH}_{2} \mathrm{PO}_{4}\right)$, potassium $1.50\left(\mathrm{~K}_{2} \mathrm{SO}_{4}\right)$, magnesium 0.5 $\left(\mathrm{MgSO}_{4}\right)$, and microelement nutrient solution. The plants were watered daily automatically (drip system) to ensure optimum moisture conditions. The thermal conditions were natural (mean daily temp. VI-VIII $19.3-22.9^{\circ} \mathrm{C}$ ). During the day, the pots stood outdoors, and at night and during the rain, they stood in an open, covered greenhouse.

Two days before sowing, soybean seeds were treated with SAROX 75 WS antifungal dressing, and on the day of sowing, they were inoculated with bacterial inoculum (nitragine) containing strains of Bradyrhizobium japonicum. Seeds were sown in early May (5 June 2019, 5 April 2020) into Mitcherlich pots contain $7 \mathrm{~kg}$ of soil (20 seeds per pot) and placed in the greenhouse. After 21 days, some seedlings were removed and five plants per pot were left.

At the flowering stage (BBCH 62-67), the pots were placed in the MICRO-CLIMA 1750 phytotron (SNIJDERS LABS) for 7 days, where cold stress was inflicted $\left(17 / 13^{\circ} \mathrm{C}\right.$ day/night), and then moved to the greenhouse where further plant growth took place. The control treatments were under natural conditions at all times (mean temperature $24 / 17^{\circ} \mathrm{C}$ day/night).

\subsection{Scope of Tests and Measurements}

Plants were harvested at full seed maturity (BBCH 97) with 10-12\% moisture content of seeds. At harvest, biometric measurements were taken for 10 plants: height, height to the first pod, number of nodes, stem dry mass, number and weight of pods per plant, and number and weight of seeds per plant. The dry mass of the stem was determined after drying at a temperature of $55^{\circ} \mathrm{C}$. Yield (seed weight per pot) and 1000 grain weight were analyzed 
from three pots (pot as a replication). In the certified Chemical Laboratory in Puławy, the content of total nitrogen in seeds was determined by the Kjeldahl method [38], crude fat by the Soxhlet method [39], water-soluble carbohydrates by the Bertrand method [40], crude fiber by the enzyme-weighing method [41], and crude ash by conventional method after wet mineralization [41], based on the average samples from objects. The protein content $(\mathrm{CP})$ of the seeds was converted according to the formula: $\mathrm{CP}=\mathrm{N} \times 6.25$ [42].

\subsection{Statistical Analyses}

The normal distribution of variables was tested using the Shapiro-Wilk test. The experiment was conducted using the complete randomization method in three replications. Seed yield results were statistically processed by analysis of variance, determining confidence intervals with Tukey's HSD test at a significance level of $p=0.05$, using STATGRAPH Plus for Windows software. The two-way analysis of variance (ANOVA) for plant structure elements, yield, and 1000 seed weight were performed as the mean for 2019 and 2020, where cold stress (two regimes: stress and control) and soybean cultivar (15 cultivars) were the experimental factors. Seed nutrient content was determined only in 2020 and developed by analysis of variance for a two-factor, no-replication experiment, determining half confidence intervals by Tukey's test at a significance level of $p=0.05$, where the interaction was treated as an error, using STATGRAPH Plus for Windows software.

\section{Results}

\subsection{Plant Morphological Features and Elements of the Yield Structure}

Cold stress inflicted on plants at flowering as well as cultivar generally significantly affected morphological traits of plants and elements of the yield structure. Cold stress significantly differentiated almost all the studied traits, i.e., plant height $(\mathrm{PH})$, number of nodes per shoot $(\mathrm{NN})$, stem dry mass (SDM), number of pods per plant (NP), pod weight per plant (WP), number of seeds per plant (NS) and seed weight per plant (WS), except for height to first pod (H1P). On the other hand, genetic factor (cultivar) significantly affected all studied traits (PH, NN, SDM, NP, WP, NS, WS, H1P). Statistical analysis of the experimental results showed significant interaction of the experimental factors and its effect only for the number of nodes (Table 1).

Table 1. Results ( $p$-values) of a two-way ANOVA on the effects of cold stress and cultivar treatments, and their interactions on the plant morphological features and elements of the yield structure.

\begin{tabular}{ccccccccccc}
\hline Treatment & PH & H1P & NN & SDM & NP & WP & NS & WS & SY & TSW \\
\hline Stress & $<0.0001$ & 0.1946 & $<0.0001$ & $<0.0001$ & $<0.0001$ & $<0.0001$ & $<0.0001$ & $<0.0001$ & $<0.0001$ & 0.4856 \\
Cultivar & $<0.0001$ & $<0.0001$ & $<0.0001$ & $<0.0001$ & $<0.0001$ & $<0.0001$ & $<0.0001$ & $<0.0001$ & $<0.0001$ & 0.4172 \\
Stress $\times$ Cultivar & 0.1052 & 0.2130 & 0.0430 & 0.1461 & 0.4762 & 0.7115 & 0.7802 & 0.5672 & 0.8385 & 0.9999 \\
\hline
\end{tabular}

PH plant height, H1P height to the first pod, NN number of nodes, SDM stem dry mass, NP number of pods, WP weight of pods, NS number of seeds per plant, WS weight of seeds per plant, SY seed yield, TSW 1000 seed weight.

On average, the plants subjected to the cold stress at the flowering stage had: $6.0 \%$ lower height (Figure 1a), 7.3\% fewer nodes (Figure 1c), 14.9\% lower stem dry mass (Figure 1d), 17.4\% lower number of pods per plant (Figure 2a), 22.0\% lower pod weight per plant (Figure 2b), 22.1\% lower number of seeds per plant (Figure 2c), and 19.1\% lower seed weight per plant (Figure 2d) compared to the control. Irrespective of the thermal conditions, significant variation in cultivars was shown for plant morphological features and elements of the yield structure. Early and very early cultivars (EC) had the lowest H1P (Figure 1b), the lowest NN, NP, NS, WP, and WS. Among this group of cultivars, Erica showed the best traits in terms of SDM, WP, NS, and WS, while Oressa showed the best traits in terms of PH, H1P, NN, and NP. On the other hand, the least favorable traits were found in cultivars: Aldana in terms of NP and NS, Augusta-PH, H1P, NN, and SDM and Annushka-WP and WS. Medium-term cultivars (MC) had the highest H1P and the lowest $\mathrm{SDM}$, while the other traits were at an average level, compared to the EC and LC groups. 
Among the cultivars of MC group, Abelina in terms of PH, H1P, SDM, WP, WS, and Merlin in terms of NN, NP, NS stood out favorably. In contrast, the weakest traits were exhibited by: Sculptor (PH, NN, NP, WP, NS), Maja (SDM, WS) and Mavka (H1P). The late and very late cultivars (LC) showed the highest SDM, NP NS, WP and WS compared to the EC and MC groups. Compared to the EC group, these traits were larger by, respectively, 14.6, 23.4, $29.9,29.4$, and $24.2 \%$. Among LC cultivars, the most favorable traits were found for GL Melanie in terms of SDM, WP, NP, NS, and WS and Petrina in terms of PH, NP. However, Madlen was the weakest cultivar in terms of almost all plant morphological traits and elements of the yield structure (PH, NN, SDM, NP, WP, NS, WS).
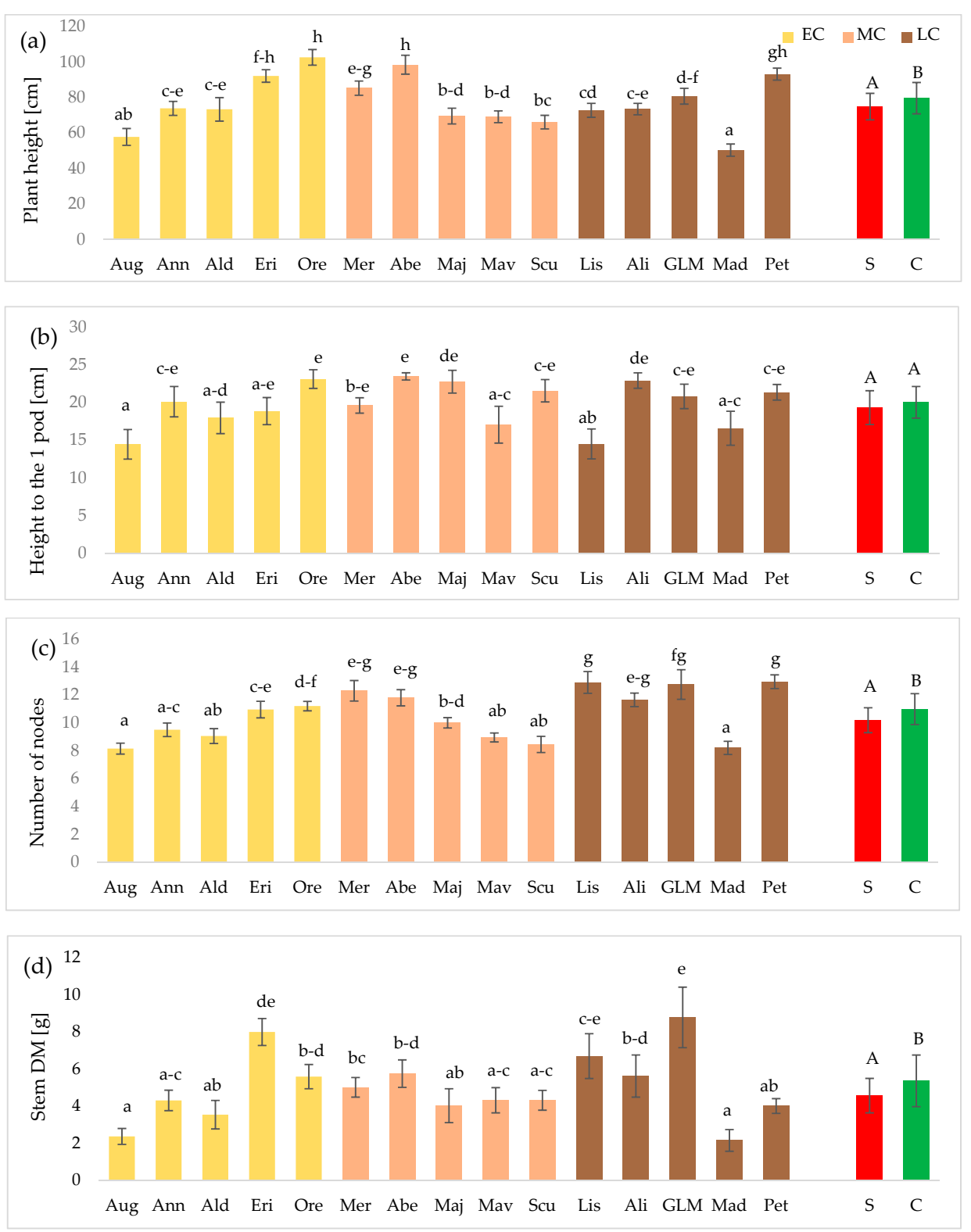

Figure 1. The effects of cold stress $(n=150)$ and cultivar $(n=20)$ treatments on the plant structure: plant height (a), height to the first pod (b), number of nodes (c), stem dry mass (d). Cultivars: Augusta (Aug), Annushka (Ann), Aldana (Ald), Erica (Eri), Oressa (Ore), Merlin (Mer), Abelina (Abe), Maja (Maj), Mavka (Mav), Sculptor (Scu), Lissabon (Lis), Aligator (Ali), GL Melanie (GLM), Madlen (Mad), Petrina (Pet); EC — very early and early cultivars, MC —-medium-early cultivars, LC—late and very late cultivars Different lowercase letters indicate significant difference between cultivars, different uppercase letters-between treatment (cold stress (S) and control (C)) according to the Tukey test $(p=0.05) ; \pm \mathrm{SD}$. 

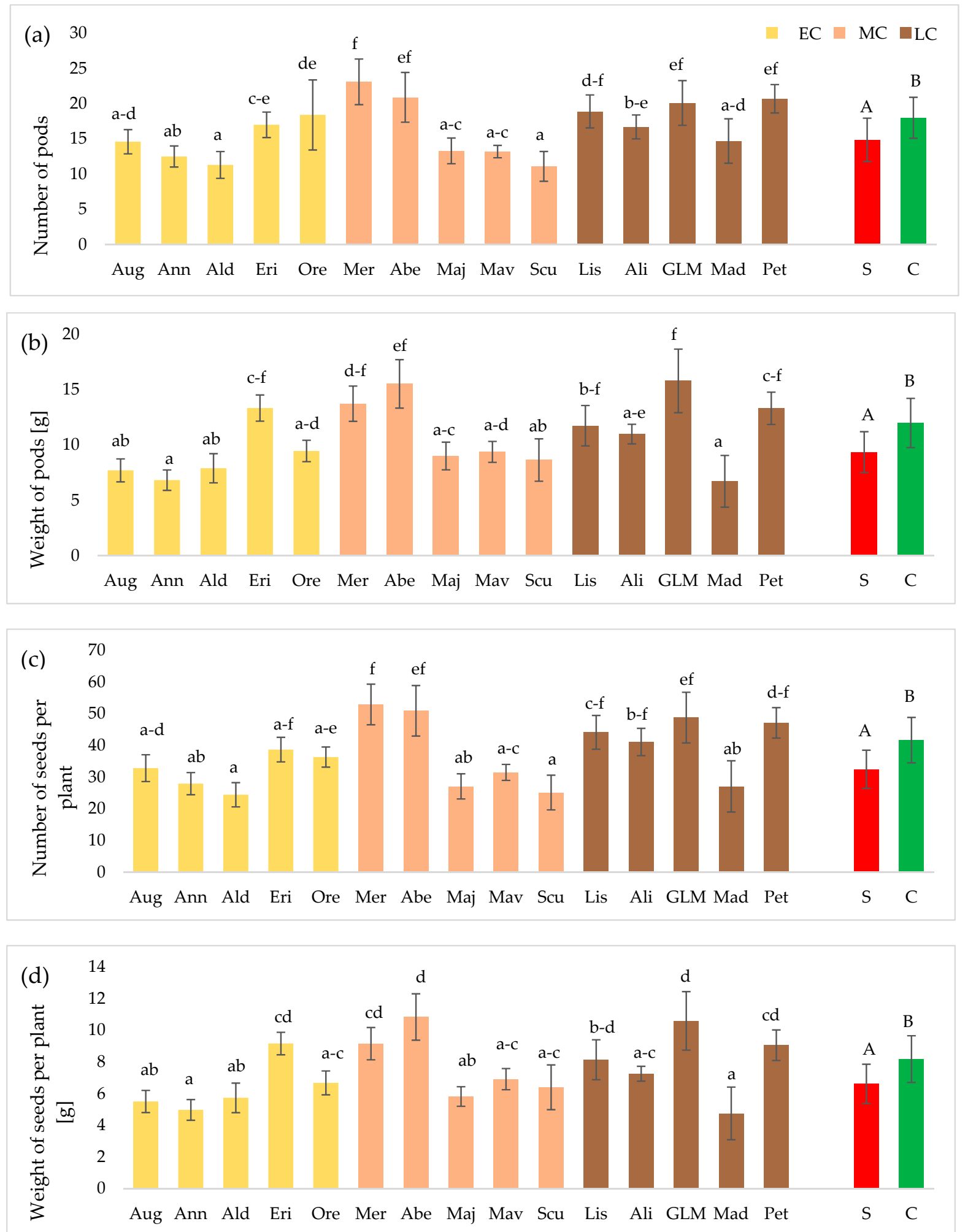

Figure 2. The effects of cold stress $(n=150)$ and cultivar $(n=20)$ treatments on the yield structure: number of pods $(a)$, weight of pods (b), number of seeds per plant (c), weight of seeds per plant (d). Cultivars: Augusta (Aug), Annushka (Ann), Aldana (Ald), Erica (Eri), Oressa (Ore), Merlin (Mer), Abelina (Abe), Maja (Maj), Mavka (Mav), Sculptor (Scu), Lissabon (Lis), Aligator (Ali), GL Melanie (GLM), Madlen (Mad), Petrina (Pet); EC—very early and early cultivars, MC-medium-early cultivars, LC-late and very late cultivars. Different lowercase letters indicate significant difference between cultivars, different uppercase letters-between treatment (cold stress (S) and control (C)) according to the Tukey test $(p=0.05)$; \pm SD. 


\subsection{Seed Yield and 1000 Seed Weight (TSW)}

Cold stress and cultivar significantly differentiated soybean seed yield, but did not affect thousand seed weight (Figure $3 a, b$ ). Cold stress at the flowering stage significantly reduced soybean seed yield (on average by $24.0 \%$ ) compared to the control. In EC and MC cultivars the average yield decrease was 19.7 and 20.1\%, respectively, while in LC cultivars-31.2\%.

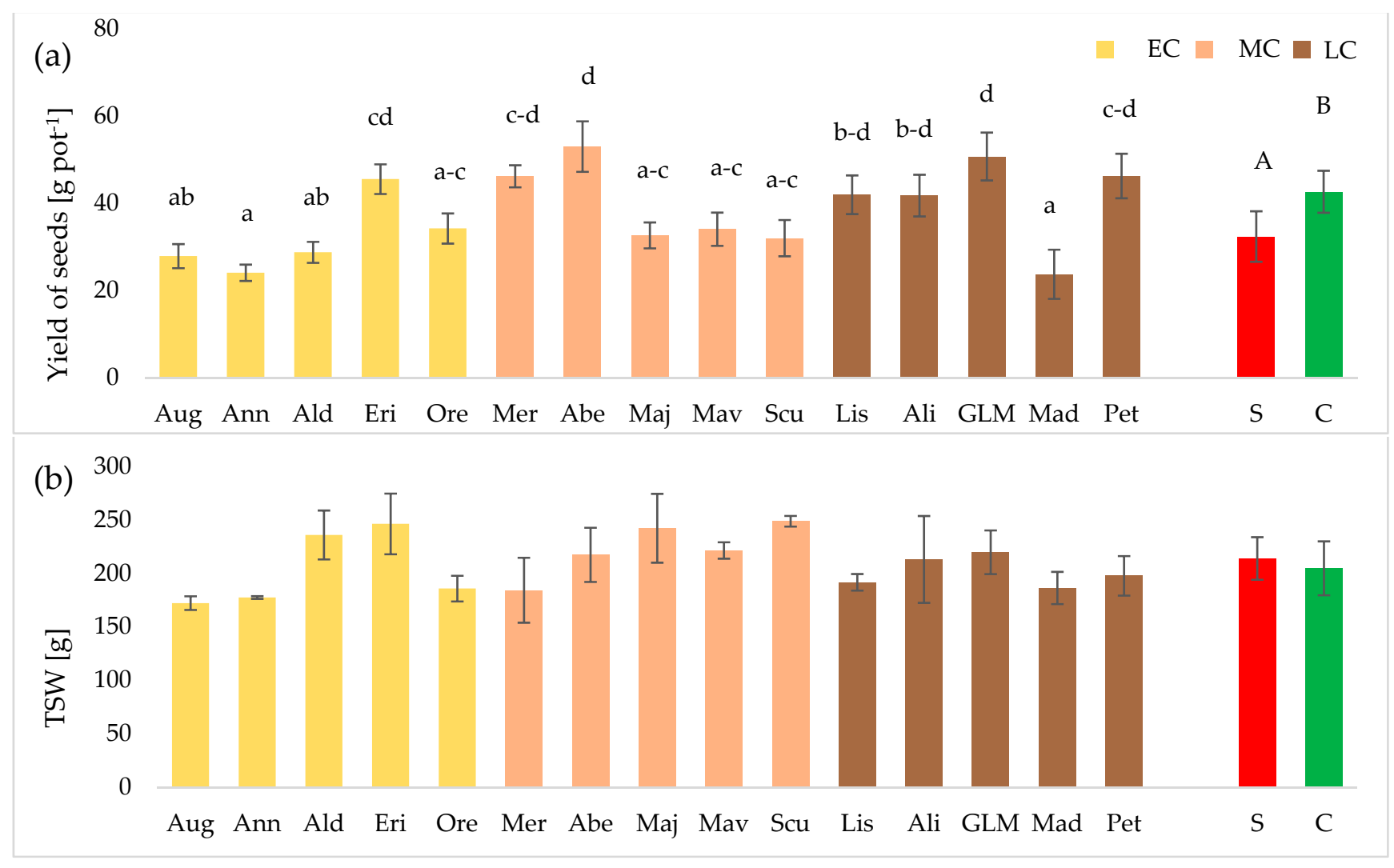

Figure 3. Yield of seeds (a) and thousand seed weight (TSW) (b) of soybean depending on the cultivar $(\mathrm{n}=6)$ and cold stress ( $\mathrm{n}=45$ ); Cultivars: Augusta (Aug), Annushka (Ann), Aldana (Ald), Erica (Eri), Oressa (Ore), Merlin (Mer), Abelina (Abe), Maja (Maj), Mavka (Mav), Sculptor (Scu), Lissabon (Lis), Aligator (Ali), GL Melanie (GLM), Madlen (Mad), Petrina (Pet); EC - very early and early cultivars, MC - medium-early cultivars, LC - late and very late cultivars. Different lowercase letters indicate significant differences between cultivars, different uppercase letters-between treatment (cold stress (S) and control (C)) according to the Tukey test $(p=0.05) ; \pm$ SD.

Irrespective of thermal conditions, significant differences in seed yield were found among soybean cultivars. EC cultivars yielded the lowest, while seed yield of MC and LC cultivars was higher by 29.2 and $22.8 \%$, respectively, compared to EC. Among the tested cultivars, the lowest yield was obtained from the early cultivar Annushka and the late cultivar Madlen, while the highest seed yield was obtained from the late cultivar GL Melanie and medium-early Abelina. Among the cultivars in the EC group, Erica gave significantly higher seed yield compared to the other EC cultivars (with the exception of Oressa), in the MC group Abelina gave significantly higher yield compared to other MC cultivars (with the exception of Merlin). In the LC group Petrina, GL Melanie, Alligator, and Lissabon gave significantly higher yield than Madlen. There was no significant interaction between the studied factors and its effect on yield and TSW of soybean.

\subsection{Chemical Composition of Seeds}

Regardless of the experimental factors, soybean seeds contained an average of $400 \mathrm{~g} \mathrm{~kg}^{-1}$ of crude protein, $211 \mathrm{~g} \mathrm{~kg}^{-1}$ of crude fat, $110 \mathrm{~g} \mathrm{~kg}^{-1}$ of water-soluble carbohydrates, 
$62.7 \mathrm{~g} \mathrm{~kg}^{-1}$ of crude fiber, and $53.3 \mathrm{~g} \mathrm{~kg}^{-1}$ of crude ash. The experimental factors significantly affected protein, fat, and ash content, while they did not differentiate sugar and fiber content (Table 2). Cold stress at the flowering stage caused a significant increase in protein content (by $4.1 \%$ on average) and ash content (by 3.8\%) and a decrease in fat content (by $6.9 \%$ ) in soybean seeds (Figure $4 a-c$ ). There was also a tendency for crude fiber and water-soluble carbohydrate contents to decrease under this factor, but the differences were not statistically proven (Figure $4 \mathrm{~d}, \mathrm{e})$.

Table 2. Results ( $p$-values) of a two-way ANOVA on the effects of cold stress and cultivar treatments on the chemical composition of soybean seeds.

\begin{tabular}{cccccc}
\hline Treatment & CP & CFa & WSC & CF & CA \\
\hline Stress & 0.0006 & $<0.0001$ & 0.2586 & 0.0973 & 0.0050 \\
Cultivar & 0.0002 & 0.0029 & 0.0860 & 0.7155 & 0.0185 \\
\hline
\end{tabular}

$\mathrm{CP}-$ crude protein, $\mathrm{CFa}-$ crude fat, WSC—-water soluble carbohydrates, $\mathrm{CF}-$ crude fiber, $\mathrm{Ca}-$ crude ash.
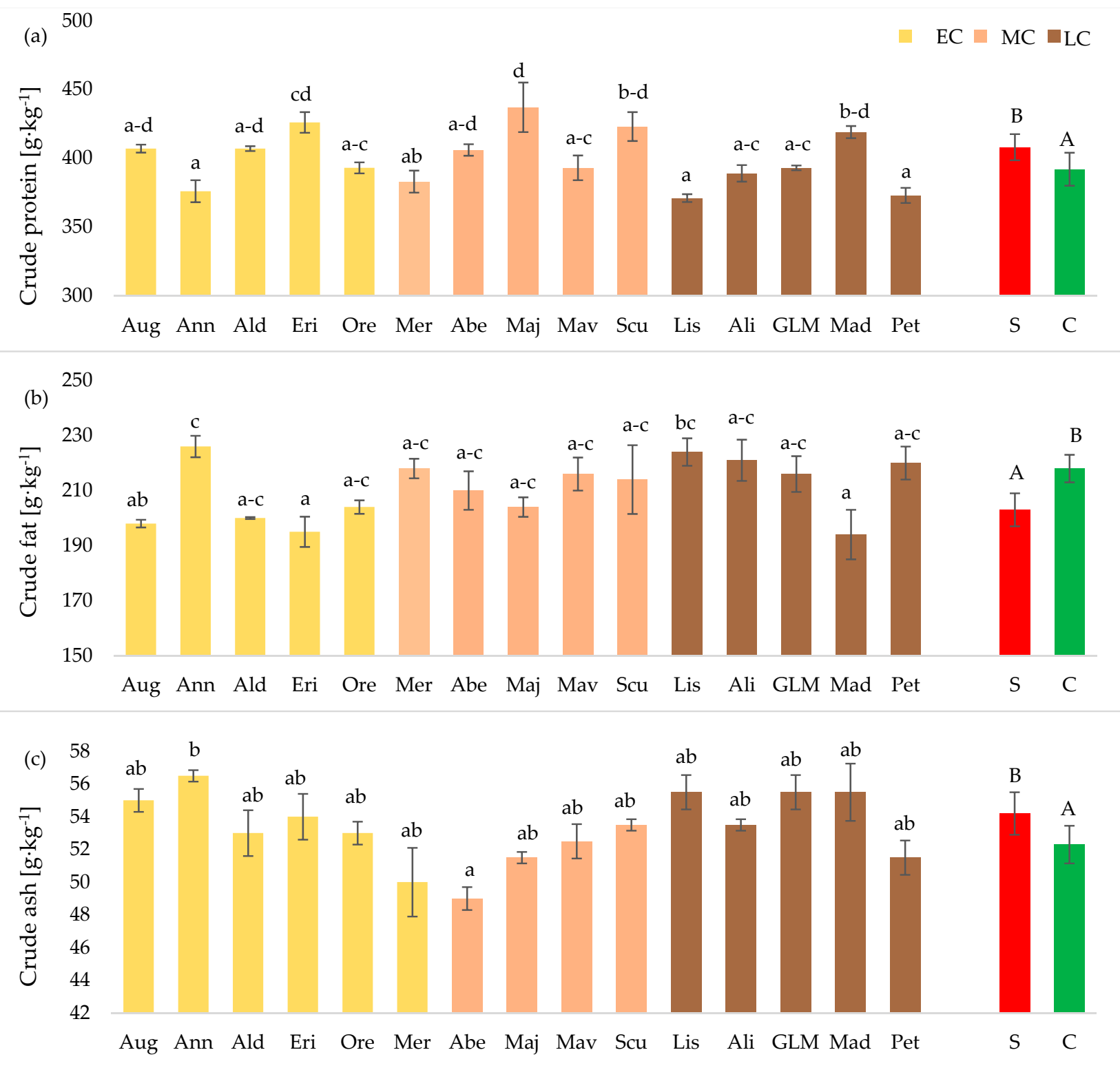

Figure 4. Cont. 

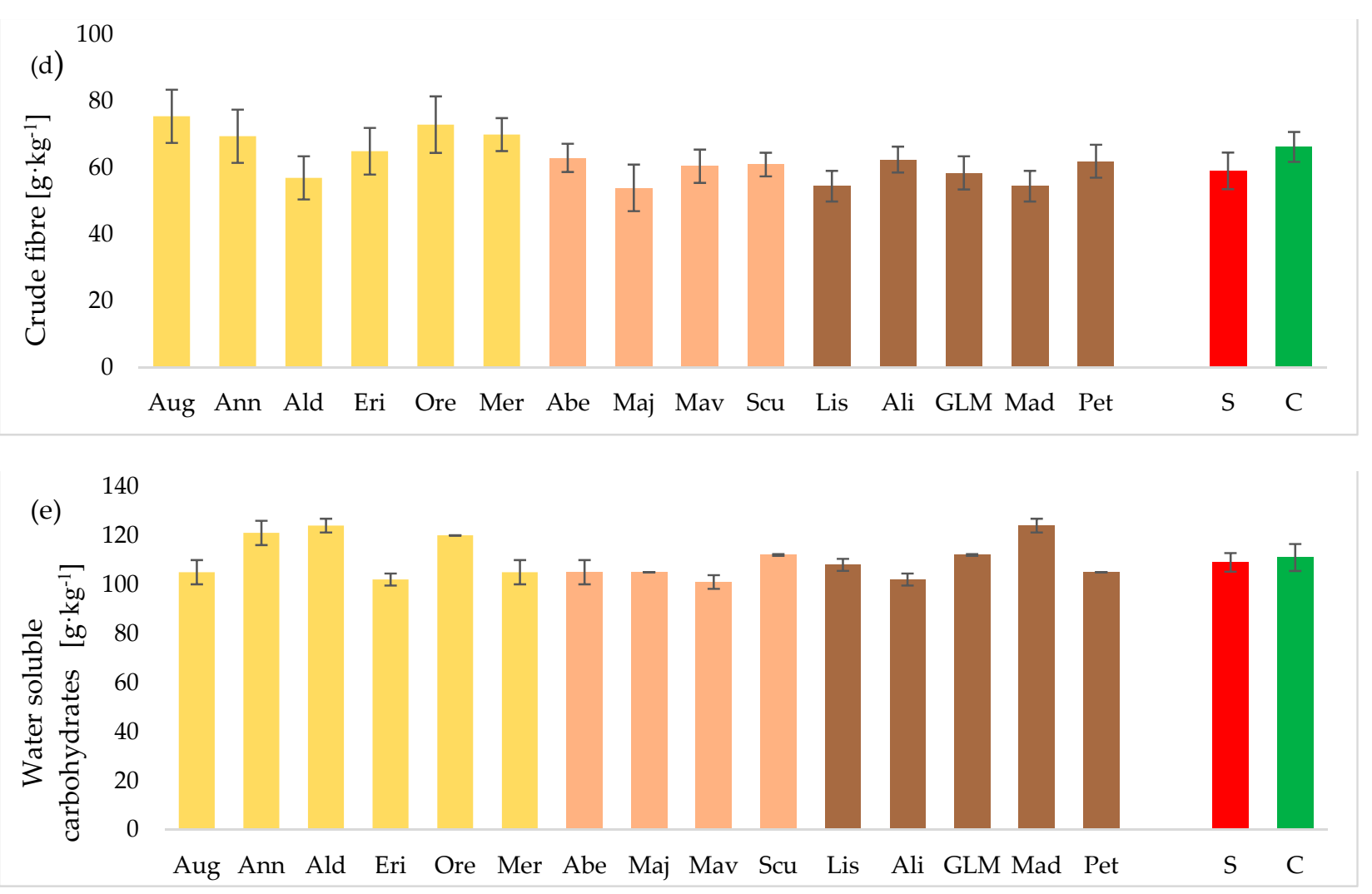

Figure 4. The effects of cold stress $(n=15)$ and cultivar $(n=2)$ treatments on chemical composition of seeds: content of crude protein (a), crude fat (b), crude ash (c), crude fibre (d), water soluble carbohydrates (e). Cultivars: Augusta (Aug), Annushka (Ann), Aldana (Ald), Erica (Eri), Oressa (Ore), Merlin (Mer), Abelina (Abe), Maja (Maj), Mavka (Mav), Sculptor (Scu), Lissabon (Lis), Aligator (Ali), GL Melanie (GLM), Madlen (Mad), Petrina (Pet)); EC-very early and early cultivars, MC-medium-early cultivars, LC - late and very late cultivars. Different lowercase letters indicate significant difference between cultivars, different uppercase letters-between treatment (cold stress (S) and control (C)) according to the Tukey test $(p=0.05) ; \pm$ SD.

The genetic factor significantly differentiated the protein, fat and ash content. The least protein in seeds was accumulated by cultivars Lissabon, Petrina, and Annushka (respectively, 371, 373, and $376 \mathrm{~g} \mathrm{~kg}^{-1}$ ), while considerably more by Madlen, Sculptor, Erica and Maja (respectively, 419, 423, 426, and $437 \mathrm{~g} \mathrm{~kg}^{-1}$ ). The remaining cultivars had an average content of this component. The content of crude fat in the seeds of the examined cultivars ranged from 194 to $226 \mathrm{~g} \mathrm{~kg}^{-1}$. Madlen and Erica accumulated the least fat, while Lissabon and Annushka accumulated significantly more of it. The genetic factor did not significantly affect the content of water-soluble and structural carbohydrates, but it differentiated the content of crude ash. The lowest content of this component in seeds was found in Abelina cultivar $\left(49.0 \mathrm{~g} \mathrm{~kg}^{-1}\right)$, while considerably higher in Annushka $\left(55 \mathrm{~g} \mathrm{~kg}^{-1}\right)$.

\section{Discussion}

Weather conditions are of great importance for the growth and development, and thus the yield of crops. The basis for determining natural and agrotechnical factors affecting the yield of crops are phenological data and dates of particular developmental stages. Linking them to the yield and elements of its structure, and weather conditions occurring at that time allows for finding the weather-yield relationship. This is especially important for crops from other climatic zones, such as soybeans. Soybean is sensitive to thermal conditions throughout its life cycle, but it is particularly sensitive to cold stress during the emergence and flowering $[5,11,43]$. Analysis of thermal conditions during the critical period, which is the flowering stage, and their effect on final yield and elements of plant 
structure and yield was useful to determine the effect of subsequent cold stress on plant structure and soybean seed yield quantity and quality.

The results of our own study showed that the weekly cold stress $\left(17 / 13^{\circ} \mathrm{C}\right.$ day /night $)$ negatively affected plant height, number of nodes, stem dry mass, number and weight of pods and seeds per plant, and soybean seed yield, compared to natural conditions (averagely $24 / 17^{\circ} \mathrm{C}$ day/night). In a study by Kurosaki and Yumoto [44], 2-week cold stress $\left(18 / 13^{\circ} \mathrm{C}\right.$ day $/$ night) at the flowering stage, negatively influenced mainly generative organs of soybean (number of pods per plant), while to a small extent vegetative parts such as number of nodes or plant height. According to the authors, plant growth was almost complete at the flowering, hence the differences were not statistically confirmed. Kumagai and Sameshima [10] showed significantly higher pod and seed number and seed yield under higher temperature conditions (daily mean $20-27^{\circ} \mathrm{C}$ ) compared to cultivation under cooler conditions $\left(19.4-22.6^{\circ} \mathrm{C}\right)$. This was due to prolonged flowering period of soybean, increased photosynthetic rate and increased leaf area. Additionally, Sionit et al. [45] showed that an increase in daily temperature from 18 to $26^{\circ} \mathrm{C}$ increased seed number and yield. According to Gass et al. [5], cold stress at the flowering stage causes insufficient pollination of flowers and consequently a low number of pods set. Slight overcooling of plants may result in non-opening of flowers and lack of pollination, resulting in the appearance of small, seedless, or deformed pods. Moderate cold stress leads to flower drooping and reduced pod set or the appearance of barren pods. Severe stress can result in complete flower drop from the plant and a complete lack of yield [11]. In the United States, a temperature increase of $0.8{ }^{\circ} \mathrm{C}$ during the postanthesis phase resulted in a $2.4 \%$ decrease in soybean seed yield in the southern states of USA (average temperature $26.7^{\circ} \mathrm{C}$ ), but the same temperature increase in the middle eastern states of USA (average temperature $22.5^{\circ} \mathrm{C}$ ) resulted in a yield increase of $1.7 \%$ [46].

Genetic variation in soybean response to high temperatures (above $30^{\circ} \mathrm{C}$ ) had been proven [47], but studies of varietal differences in response to low temperature at flowering and the effect of stress on seed yield, are not numerous. Our own study showed that LC cultivars responded more strongly to cold stress as well as exhibited higher yield loss under such conditions than EC and MC cultivars. Kumagai and Sameshima [10] showed that a few degrees increase in temperature under cooler climate conditions (mean daily temperature 19.4-22. $6^{\circ} \mathrm{C}$ ) caused an increase in soybean seed yield in late-maturing cultivars that was not observed in early-maturing cultivars. The authors explain this differential response to temperature during the flowering period by the different growing season length and day length requirements for each cultivar. Under higher temperature conditions, the flowering period of late soybean cultivars was prolonged and, besides, the total number of open flowers increased, which resulted in the setting of more pods and seeds and, consequently, in a higher yield than in early cultivars. This was also confirmed by other authors $[34,48]$. The differential response to weather conditions of two soybean genotypes is also reported by Kołodziej and Pisulewska [49]. The authors show that the meteorological factors had a stronger influence on the yield of the small-seeded cultivar Nawiko than the large-seeded cultivar Aldana, with seed and fat yields showing the highest susceptibility to weather conditions (coefficient of variation 13.6 and 19.3\% in Nawiko, 6.1 and 3.5\% in Aldana, respectively). Additionally, in the study of Kurosaki and Yumoto [44], they showed varietal variation in response to low temperature at flowering stage. The more stress-sensitive cultivar (Toyomusume) had significantly lower number of pods per plant (by $64 \%$ ), number of seeds per pod (by $28 \%$ ), and 100 seed weight (by $44 \%$ ) after chilling compared to the control, while the more tolerant cultivar (Hayahikari) had significantly reduced only the number of seeds per pod (by 13\%), while the number of pods per plant and 100 seed weight decreased slightly (by 6 and 5\%, respectively). Rahman et al. [9] indicate that in the cool climate of New Zealand, soybean development from flowering to maturity was mainly controlled by temperature, as indicated by the high regression coefficients obtained in the regression analysis for two cultivars: Northern Conquest $\left(\mathrm{r}^{2}=0.95\right)$ and March $\left(\mathrm{r}^{2}=0.88\right)$. Obtaining cultivars with greater tolerance to low temperatures, especially shortly before 
and during the flowering stage, is one of the most important objectives of soybean breeding in cold climates [11].

The results show that under the influence of cold stress at the flowering stage, protein and ash contents increased significantly, crude fat contents decreased, while the concentration of water-soluble and structural carbohydrates in soybean seeds did not change. In a meta-analysis of environmental studies, Rotundo and Westgate [50] showed a negative relationship between protein and fat concentrations in soybean seeds. This is a difficult task especially for growers who want to increase seed fat content while maintaining high protein levels. Oil is important to the soybean industry because of its high use in edible oil production, but also as a source of a major renewable feedstock in biodiesel production. Under low temperature conditions, various authors have shown an increase in protein content and a decrease in fat content in soybean seeds [51-56]. In a study by Kołodziej and Pisulewska [49], an increase by $1{ }^{\circ} \mathrm{C}$ of minimal air temperature $\left(13.4{ }^{\circ} \mathrm{C}\right)$ at the soybean flowering stage, resulted in an increase in fat yield by $7.7 \mathrm{~kg} \cdot \mathrm{ha}^{-1}$, while the same increase in average daily temperature $\left(19.9^{\circ} \mathrm{C}\right)$ contributed to an increase in fat yield by $23.3 \mathrm{~kg} \cdot \mathrm{ha}^{-1}$, with similar values of correlation coefficients $(\mathrm{R}=0.916$ and 0.922 respectively) and their level of significance $(p=0.01)$.

Soluble sugars are the main source of energy in the fermentation of sweets in food products such as soy milk [57]. However, certain sugars (raffinose, stachyose) have negative effects on soybean seed quality, contributing to reduced animal performance [58]. Wolf et al. [51] investigated the content of soluble sugars in soybeans after planting in the temperature range $18 / 13{ }^{\circ} \mathrm{C}$ and $33 / 28{ }^{\circ} \mathrm{C}$ day/night. According to the authors, among the analyzed sugars, the sucrose concentration decreased by $56 \%$ with the temperature increase by $15^{\circ} \mathrm{C}$, and the stachyose showed a slight decrease, while the remaining sugars remained unchanged.

In this study it was shown that protein, fat and ash contents in soybean seeds significantly depended on the genetic factor (cultivar), which confirms the results of other authors. Piper and Boote [59] showed variation in protein and fat concentration in 20 soybean cultivars, with protein content significantly dependent only on cultivar, while fat content on cultivar and temperature related to latitude. Further, other authors proved significant effect of genotype on protein [54], fat [55,60,61], ash [61], and carbohydrate (raffinose and stachyose) contents [62]. The results presented in this study showed little anecdotal varietal variation in sugar content, which is consistent with the study of Alsajri et al. [55]. On the other hand, Kozak et al. [63] proved that the chemical composition of soybean seeds was more dependent on climatic conditions than on cultivar.

\section{Conclusions}

Cold stress at the flowering stage negatively affected the elements of plant structure and seed yield of soybean, with the greatest yield decrease shown in late cultivars, while a smaller and similar decrease in early and medium-early cultivars. Significant genetic differentiation was shown in morphological structure and yielding of cultivars. Early cultivars had the smallest parameters of plant structure and yield traits, while late cultivars by the largest ones. Cold stress at the flowering stage caused a significant increase in protein and ash content and a decrease in fat concentration in soybean seeds, while it did not differentiate soluble and structural carbohydrate content. Differences in nutrient content among cultivars were a genetic trait not related to cultivar maturity. The high genetic variability in soybean indicates that it has significant adaptive potential to different climatic conditions, so further research is needed to capture environmental variability in different regions to expand the range of producers in cooler climates.

Author Contributions: Conceptualization, M.S.; methodology, M.S., K.C. and A.S.-W.; investigation, M.S., K.C., A.S.-W. and M.P.; data analysis, M.S., K.C. and A.K.; writing-original draft preparation, M.S.; writing-review and editing, K.C., A.K., A.S.-W. and M.P.; visualization, M.S. and K.C.; supervision, M.S.; funding acquisition, M.S. All authors have read and agreed to the published version of the manuscript. 
Funding: The studies have been supported by the Polish Ministry of Science and Higher Education within the statutory activity of the Institute of Soil Science and Plant Cultivation-State Research Institute, task 1.23 Biological and agrotechnical aspects of soybean (Glycine max (L.) Merr.) reaction to cold stress.

Institutional Review Board Statement: Not applicable.

Informed Consent Statement: Not applicable.

Data Availability Statement: The data presented in this study are available upon request from the first author.

Acknowledgments: The authors thank Jolanta Kaźmierczak, Monika Antoniak, Sławomir Pękala and Waldemar Kopacz for their technical support while conducting the experiments and assessments.

Conflicts of Interest: The authors declare no conflict of interest. The funders had no role in the design of the study; in the collection, analyses, or interpretation of data; in the writing of the manuscript, or in the decision to publish the results.

\section{References}

1. FAOSTAT 2020. Available online: http://www.fao.org/faostat/en/-data/QC (accessed on 12 January 2021).

2. Kotecki, A.; Lewandowska, S. (Eds.) Studies on the Cultivation of Soybean (Glycine max (L.) Merrill) in South-Western Poland; UP: Wrocław, Poland, 2020; p. 226. (In Polish)

3. Bellaloui, N.; Bruns, H.A.; Abbas, H.K.; Mengistu, A.; Fisher, D.K.; Reddy, K.N. Agricultural practices altered soybean seed protein, oil, fatty acids, sugars, and minerals in the Midsouth USA. Front. Plant Sci. 2015, 6, 1-14. [CrossRef]

4. Bezdicek, D.F.; Abede, E.B.; Evans, D.W.; Witters, R.E. Evaluation of peat and granular inoculum for soybean yield and N fixation under irrigation. J. Agron. 1978, 70, 865-868. [CrossRef]

5. Gass, T.; Schori, A.; Fossati, A.; Soldati, A.; Stamp, P. Cold tolerance of soybean (Glycine Max (L.) Merr.) during the reproductive phase. Eur. J. Agron. 1996, 5, 71-88. [CrossRef]

6. Gaynor, L.G.; Lawn, R.J.; James, A.T. Agronomic studies on irrigated soybean in southern New South Wales. I. Phenological adaptation of genotypes to sowing date. Crop Past. Sci. 2011, 62, 1056-1066. [CrossRef]

7. Wu, T.; Li, J.; Wu, C.; Sun, S.; Mao, T.; Jiang, B.; Hou, W.; Han, T. Analysis of the independent- and interactive-photo-thermal effects on soybean flowering. J. Integr. Agric. 2015, 14, 622-632. [CrossRef]

8. Câmara, G.M.S.; Sediyama, T.; Dourado-Neto, D.; Bernardes, M.S. Influence of photoperiod and air temperature on the growth, flowering and maturation of soybean (Glycine Max (L.) Merrill). Sci. Agric. 1997, 54, 149-154. [CrossRef]

9. Rahman, M.M.; Hampton, J.G.; Hill, M.J. Soybean development under the cool temperate environment of Canterbury, New Zealand. J. New Seeds 2008, 4, 17-36. [CrossRef]

10. Kumagai, E.; Sameshima, R. Genotypic differences in soybean yield responses to increasing temperature in a cool climate are related to maturity group. Agric. For. Meteorol. 2014, 198-199, 265-272. [CrossRef]

11. Ohnishi, S.; Miyoshi, T.; Shirai, S. Low temperature stress at different flower developmental stages affects pollen development, pollination, and pod set in soybean. Environ. Exp. Bot. 2010, 69, 56-62. [CrossRef]

12. Nawracała, J. Efektywność kwitnienia zróżnicowanych genotypów soi (Glycine max (L.) Merrill) w warunkach środowiskowych Wielkopolski. Oilseed Crop. 2001, 26, 27-44. (In Polish)

13. Gibson, L.R.; Mullen, R.E. Influence of day and night temperature on soybean seed yield. Crop Sci. 1996, 36, 98-104. [CrossRef]

14. Wheeler, T.R.; Craufurd, P.Q.; Ellis, R.H.; Porter, J.R.; Prasad, P.V.V. Temperature variability and the yield of annual crops. Agric. Ecosyst. Environ. 2000, 82, 159-167. [CrossRef]

15. Schlenker, W.; Roberts, M.J. Estimating the Impact of Climate Change on Crop Yields: The Importance of Nonlinear Temperature Effects; Working Paper; National Bureau of Economic Research: Cambridge, MA, USA, 2008; p. 13799.

16. Mourtzinis, S.; Specht, J.E.; Lindsey, L.E.; Wiebold, W.J.; Ross, J.; Nafziger, E.D.; Herman, K.; Nathan, M.; Devillez, P.L.; Arriaga, F.J.; et al. Climate-induced reduction in US-wide soybean yields underpinned by region and in season specific responses. Nat. Plants 2015, 1, 14026. [CrossRef] [PubMed]

17. Gao, C. The future of CRISPR technologies agriculture. Nat. Rev. Mol. Cell Biol. 2018, 19, 275-276. [CrossRef] [PubMed]

18. Jiang, B.; Khan, M.A.A.; Song, W.; Sun, S.; Zhang, C.; Wu, T.; Wu, C.; Zhang, S. Natural variations of FT family genes in soybean varieties covering a wide range of maturity groups. BMC Genom. 2019, 20, 230. [CrossRef]

19. Kozyra, J.; Doroszewski, A.; Nieróbca, A. Zmiany klimatyczne i ich przewidywany wpływ na rolnictwo w Polsce. Studia I Rap. IUNG-PIB 2009, 14, 243-257. (In Polish) [CrossRef]

20. Thompson, J.A.; Nelson, R.L. Utilization of diverse germplasm for soybean yield improvement. Crop Sci. 1998, 38, 1362-1368. [CrossRef]

21. Mikel, M.A.; Diers, B.W.; Nelson, R.L.; Smith, H.H. Genetic diversity and agronomic improvement of North American soybean germplasm. Crop Sci. 2010, 50, 1219-1229. [CrossRef] 
22. Kusano, K.; Baxter, I.; Fukushima, A.; Oikawa, A.; Okazaki, Y.; Nakabayashi, R.; Bouvrette, D.J.; Achard, F.; Jakubowski, A.R.; Ballam, J.M.; et al. Assessing metabolomic and chemical diversity of a soybean lineage representing 35 years of breeding. Metabolomics 2015, 11, 261-270. [CrossRef]

23. Holmberg, S.A. Soybeans for cool temperate climates. Agri. Horti. Genet. 1973, 31, 1-20.

24. Schmid, J.; Keller, E.R. The behavior of three cold-tolerant and a standard soybean variety in relation to the level and the duration of a cold stress. Can. J. Plant Sci. 1980, 60, 821-829. [CrossRef]

25. Hume, D.J.; Jackson, A.K.H. Pod formation in soybeans at low temperatures. Crop Sci. 1981, 21, 933. [CrossRef]

26. Kurosaki, H.; Yumoto, S.; Matsukawa, I. Pod setting pattern during and after low temperature and the mechanism of cold-weather tolerance at the flowering stage in soybeans. Plant Prod. Sci. 2003, 6, 247-254. [CrossRef]

27. Hou, G.; Ablett, G.R.; Pauls, K.P.; Rajcan, I. Environmental effects on fatty acid levels in soybean seed oil. J. Am. Oil Chem. Soc. 2006, 83, 759-763. [CrossRef]

28. Shao, H.B.; Chu, L.Y.; Lu, Z.H.; Kang, C.M. Primary antioxidant free radical scavenging and redox signaling pathways in higher plant cells. Int. J. Biol. Sci. 2008, 4, 8-14. [CrossRef]

29. Thomas, J.M.G.; Boote, K.J.; Allen, L.H.; Gallo-Meagher, M.; Davis, J.M. Elevated temperature and carbon dioxide effects on soybean seed composition and transcript abundance. Crop Sci. 2003, 43, 1548-1557. [CrossRef]

30. Wilson, R.F. Seed composition. In Soybeans: Improvement, Production, and Uses; Boerma, H.R., Specht, J.E., Wilson, R.F., Eds.; The American Society of America, Crop Science Society of America, Soil Science Society of America: Madison, WI, USA, 2004; pp. 621-677. [CrossRef]

31. Yaklich, R.W.; Vinyard, B.T. A method to estimate soybean seed protein and oil concentration before harvest. J. Am. Oil Chem. Soc. 2004, 81, 1021-1027. [CrossRef]

32. Rinker, K.; Nelson, R.; Specht, J.; Sleper, D.; Cary, R.; Cianzio, S.; Casteel, S.; Conley, S.; Chen, P.; Davis, V.; et al. Genetic improvement of soybean in maturity groups II, III, and IV. Crop Sci. 2014, 54, 1-14. [CrossRef]

33. Patil, G.; Mian, R.; Vuong, T.; Pantalone, V.; Song, Q.; Chen, P.; Shannon, J.; Carter, T.C.; Nguyen, H.T. Molecular mapping and genomics of soybean seed protein: A review and perspective for the future. Theor. Appl. Genet. 2017, 130, 1975-1991. [CrossRef]

34. Mourtzinis, S.; Gaspar, A.P.; Naeve, S.L.; Conley, S.P. Planting date, maturity, and temperature effects on soybean seed yield and composition. J. Agron. 2017, 109, 2040-2049. [CrossRef]

35. Kumar, V.; Rani, A.; Solanki, S.; Hussain, S.M. Influence of growing environment on the biochemical composition and physical characteristics of soybean seed. J. Food Compos. Anal. 2006, 19, 188-195. [CrossRef]

36. EU Common Catalogue of Varieties of Agricultural Plant Species. Consolidated Version. 20 September 2019. Available online: https:/ / ec.europa.eu/food/sites/food/files/plant/docs/plant_variety_catalogues_agriculturalplant- (accessed on 6 September 2021).

37. Mourtzinis, S.; Conley, S.P. Delineating soybean maturity groups across the United States. Agron. J. 2017, 109, 1397-1403. [CrossRef]

38. Kjeldahl, J.A. New method for the determination of nitrogen in organic matter. Z. Anal. Chem. 1883, 22, 366-382. [CrossRef]

39. Soxhlet, F. The weight analytic determination of milk fat. Polytech. J. 1879, 232, 461-465.

40. Official Methods of Analysis of the AOAC. Wyd. XX; Association of Official Analytical Chemists: Rockville, MD, USA, 2016.

41. Nogala-Kałucka, M. (Ed.) Analiza Żywności. In Wybrane Metody Oznaczeń Jakościowych i Ilościowych Składników Żywności; UP: Poznan, Poland, 2016; p. 165. (In Polish)

42. Jones, D.B. Factors for Converting Percentages of Nitrogen in Foods and Feed into Percentages of Proteins; Circular, 1941, No. 183 (Original Version, 1931); United States Department of Agriculture: Washington, DC, USA, 1931.

43. Staniak, M.; Stępień-Warda, A.; Czopek, K.; Kocira, A.; Baca, E. Seeds quality and quantity of soybean [Glicine max (L.) Merr.] cultivars in response to cold stress. Agronomy 2021, 11, 520. [CrossRef]

44. Kurosaki, H.; Yumoto, S. Effects of low temperature and shading during flowering on the yield components in soybeans. Plant Prod. Sci. 2003, 6, 17-23. [CrossRef]

45. Sionit, N.; Strain, B.R.; Flint, E.P. Interaction of temperature and $\mathrm{CO}_{2}$ enrichment on soybean: Photosynthesis and seed yield. Can. J. Plant Sci. 1987, 67, 629-636. [CrossRef]

46. Hatfield, J.L.; Boote, K.J.; Kimnball, B.A.; Ziska, L.H.; Izaurralde, R.C.; Ort, D.; Thomson, A.M.; Wolfe, D. Climate impacts on agriculture: Implications for crop production. Agron. J. 2011, 103, 351-370. [CrossRef]

47. Salem, M.A.; Kakani, V.G.; Koti, S.; Reddy, K.R. Pollen-based screening of soybean genotypes for high temperatures. Crop Sci. 2007, 47, 219-231. [CrossRef]

48. Kantolic, A.G.; Slafer, G.A. Development and seed number in indeterminate soybean as affected by timing and duration of exposure to long photoperiods after flowering. Ann. Bot. 2007, 99, 925-933. [CrossRef] [PubMed]

49. Kołodziej, J.; Pisulewska, E. Wpływ czynników meteorologicznych na plon nasion i tłuszczu oraz zawartość tłuszczu w nasionach dwóch odmian soi. Oilseed Crop. 2000, 21, 759-773. (In Polish)

50. Rotundo, J.L.; Westgate, M.E. Meta-analysis of environmental effects on soybean seed composition. Field Crop. Res. 2009, 110, 147-156. [CrossRef]

51. Wolf, R.B.; Cavins, J.F.; Kleiman, R.; Black, L.T. Effect of temperature on soybean seed constituents: Oil, protein, moisture, fatty acids, amino acid, and sugars. J. Am. Oil Chem. Soc. 1982, 59, 230-232. [CrossRef] 
52. Dornbos, D.L.; Mullen, R.E. Soybean seed protein and oil contents and fatty acid composition adjustments by drought and temperature. J. Am. Oil Chem. Soc. 1992, 69, 228-231. [CrossRef]

53. Khan, A.Z.; Shah, P.; Khan, H.; Nigar, S.; Perveen, S.; Shah, M.K.; Amanullah; Khalil, S.K.; Munir, S.; Zubair, M. Seed quality and vigor of soybean cultivars as influenced by canopy temperature. Pak. J. Bot. 2011, 43, 643-648.

54. Rotundo, J.L.; Miller-Garvin, J.E.; Naeve, S.L. Regional and temporal variation in soybean seed protein and oil across the United States. Crop Sci. 2016, 56, 797-808. [CrossRef]

55. Alsajri, F.A.; Wijewardana, C.; Irby, J.T.; Bellaloui, N.; Krutz, L.J.; Golden, B.; Gao, W.; Reddy, K.R. Developing functional relationships between temperature and soybean yield and seed quality. J. Agron. 2020, 112, 194-204. [CrossRef]

56. Nakagawa, A.C.; Ario, N.; Tomita, Y.; Tanaka, S.; Murayama, N.; Mizuta, C.; Iwaya-Inoue, M.; Ishibashi, Y. High temperature during soybean seed development differentially alters lipid and protein metabolism. Plant Prod. Sci. 2020, 23, 504-512. [CrossRef]

57. Hou, A.; Chen, P.L.; Shi, A.; Alloatti, J.; Zhang, B.; Wang, Y. Sugar variation soybean seed associated with a rapid extraction and quantification method. Int. J. Agron. 2009, 2009, 484571. [CrossRef]

58. Arendt, E.K.; Zannini, E. Cereal Grains for the Food and Beverage Industries; Woodhead Publishing: Cambridge, UK, 2013; pp. 409-438. [CrossRef]

59. Piper, E.L.; Boote, K.J. Temperature and cultivar effects on soybean seed oil and protein concentrations. J. Am. Oil Chem. Soc. 1999, 76, 1233-1241. [CrossRef]

60. Nascimento, M.; Finoto, E.L.; Sediyama, T.; Cruz, C.D. Adaptability and stability of soybean in terms of oil and protein content. Crop Breed. Appl. Biotechnol. 2010, 10, 48-54. [CrossRef]

61. Biel, W.; Gawęda, D.; Łysoń, E.; Hury, G. Wpływ czynników genetycznych i agrotechnicznych na wartość odżywczą nasion soi. Acta Agroph. 2017, 24, 395-404. (In Polish)

62. Kumar, V.; Rani, A.; Goyal, L.; Dixit, A.K.; Manjaya, J.G.; Dev, J.; Swamy, M. Sucrose and raffinose family oligosaccharides (RFOs) in soybean seeds as influenced by genotype and growing location. J. Agric. Food Chem. 2010, 58, 5081-5085. [CrossRef] [PubMed]

63. Kozak, M.; Malarz, W.; Kotecki, A.; Černý, I.; Serafin-Andrzejewska, M. The effect of different sowing rate and Asahi SL biostimulator. Oilseed Crop. 2008, 29, 217-230. (In Polish) 